\title{
SELECTION OF GOOD MALE DATE PALM POLLINATORS FOR IMPROVING BOTH YIELDS AND FRUIT QUALITY, USING MORPHOLOGICAL CHARACTERIZATION AND GENETIC RELATIONSHIPS OF POLLINATORS USING ISSR MARKERS
}

\author{
Zeinab A.M. Abo-Rekab ; T.M. El-Kafrawy ${ }^{* *}$ and Ghada A.A.** \\ * Horticulture Research Institute, Agricultural Research Center, Giza, Egypt. \\ ** Central Laboratory of Date Palm Researches and Development, Agricultural Research Center, \\ Giza, Egypt.
}

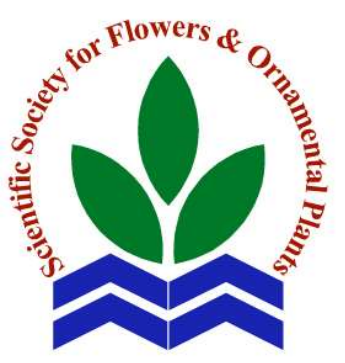

Scientific J. Flowers \& Ornamental Plants, 1(1):55-71 (2014).

Received:

9/2/2014

Revised by:

Prof. Dr. M.R.A. Nesiem, Cairo Univ.

Prof. Dr. Wafaa T. Saeed, Hort. Res. Inst., ARC.
ABSTRACT: This investigation was carried out during three successive seasons (2011, 2012 and 2013) at Siwa Oasis, Matruh Governorate and Tamiya District, Fayoum Governorate. The investigation included three types of experiments; the first was concerned with the evaluation of twenty chosen seedling palm males in order to select the most promising males. Five male pollinizers were selected according to spathes number, flowers number/spathe, start and duration of spathe burst, pollen grains weight, pollen grains viability (at Siwa Oasis in 2011 and 2012 seasons). The numerical selection of selected male palms showed that pollinizer No. 5 (98.9 units), No. 14 (98.8 units), No. 7 (83.6 units), No. 12 (81.9 units) and No. 13 (81.8 units).

The results indicated that the five selected pollinators increased the yield of both Seewy and Barhee cultivars in both two seasons (2012 and 2013) grown at Tamiya District, Fayoum Governorate. Pollinizer No. 12 induced an early harvesting in both Barhee and Seewy cultivars, while pollinizer No. 7 gave the highest yield in both Seewy and Barhee cultivars as well as moisture percentage. Meanwhile, pollinizer No. 12 gave the highest values of total sugar content and TSS \% in Seewy cultivar. The results indicated that pollinizer No. 13 gave the highest dry matter \%. Also, the results indicated that pollinizer No. 14 gave the highest fruit dimensions as well as both fruit weight and flesh weight. The pollinizer No. 5 gave the lowest seed weight in both two seasons. The selected five pollinators seedling were genetically discriminated by inter-simple sequence repeats for characterization and construction of genetic linkage maps and the molecular genetic diversity among the five selected pollinators. The results indicated that pollinizers No. 12 and 14 recorded the highest similarity $(100 \%)$, while the lowest similarity $(0.0 \%)$ was detected between pollinizer No. 7 and No. 13.

Key words: Selection, male, date palm, pollinators, ISSR analysis.

\section{INTRODUCTION}

Date palm (Phoenix dactylifera $\mathrm{L}$.) is an important commercial crop of many countries of the world and plays an important role in the economical development of these countries. The date palm has probably been cultivated in what is known today as Southern Iraq (Mesopotamia) since 3500 B.C. or earlier, and little later in Egypt. In Egypt, date palm has been discovered since prehistoric times 
and can be grown under unfavorable environmental conditions in all governorates. There are three main types of dates based on moisture content; soft, semi-dry and dry types.

According to the latest statistical estimates of Ministry of Agriculture (2012), the number of date palm trees in Egypt is about 1253488 produced yearly about 1400072 tons of soft, semi-dry and dry fruits. Fayoum Governorate presents one of the main areas of date production in Egypt, especially semi-dry date cultivars. In Fayoum Governorate, the number of date palm trees is about one million with a yearly production of about 61.560 tons of fruits, there of about 130 thousand seedling male palms. Date flowers tend to set parthenocarpically if they are not pollinated and all three carpels remained and developed to three small fruits with no value. So, pollination is one of the major practices to insure good fruit production. Artificial pollination is considered the major mean for commercial date production (Kotb, 1993). The pollination efficiency is affected by several factors and consequently fruit set is highly dependent on these factors. The pollination time of flowering period of male palm, the type of pollen, pollen viability and amount as well as the female flowers, respectively are considered the main factors involved in this process (El-Salhy et al., 1997). Males are highly variable in their growth, vigor, flowering time, spathe characteristics and pollen quality (Mohamed, 2004). Date palm growers use pollen that is readily available. As a result, yield and fruit quality of palms differ greatly from one to another. The growers are now beginning to realize the need for selection of males (ElSalhy et al., 1997). Recently developed techniques based on polymerase chain reaction (PCR), offer a new tool for genetic analysis and construction of linkage maps. Genetic diversity is the bases for successful crop improvement and can be estimated by different methods which include the use of agronomic characterization and DNA finger printing (Becelaere et al., 2005). One of the most widely used applications is the ISSR technique which depends on the identification of markers linked to traits of interest without the necessity of mapping the entire genome. In order to overcome some of the production problems of date palm under Fayoum conditions, this investigation is aimed to study the following points:

1- Evaluate different male trees and selecting the suitable and highly potent of them to be used in pollinating female palm trees of Seewy and Barhee cultivars, using vegetative fruiting and ISSR as a tool for identification and for determination of genetic diversity among the different seedling males of date palm.

2- Study the effect of the selected pollen palm males on fruit-setting, yield, fruit physical and chemical characteristics, as well as fruit maturity and time of Seewy and Barhee date cultivars grown in Fayoum governorate.

\section{MATERIALS AND METHODS}

This investigation was conducted in Siwa Oasis, Matruh Governorate in three successive seasons; 2011, 2012 and 2013. The first part of the present investigation included 20 chosen seedling palm males in order to select the most promising males. Evaluation of the selected males based on their vegetative growth and morphological aspects of trees and spathes, as well as pollen grains viability and weight. The second with evaluation using inter-simple sequence repeats (ISSR) to identify the genetic diversity among selected males. Five pollinizers were selected as grown vigorously and marked to complete investigation in two seasons (2012 and 2013). Moreover, the third goal was studying the effect of selected pollen grains on yield and fruit quality of female Seewy and Barhee palm at Tamiya District, Fayoum Governorate. The male spathes were collected once spathe crashing and strands were separated individually and dried at room temperature to avoid high moisture. 
Dusting the female inflorescence by striking 10 male strands with hand on it. Six date palm trees were about 20 years old grown on clay soil, uniform in growth and vigor, subjected to the usual horticultural management. Three spathes on each palm were selected and pollination was made 3 days after spathe cracking. Prior to cracking, female spathes were covered by paper bags within 3 days from cracking. Pollinated female spathes were still covered until fruit set was insured. Experimental treatments were arranged in a randomized complete block design with three replications (one palm tree represented each replicate).

\section{Date male morphological characteristics:}

1- Palm height and girth: The height and the trunk girth for each male palm used were measured in meters.

2- Leaves number: The number of leaves per male palm was counted and recorded.

3- Leaf morphology: Morphology of leaves was studied on four full grown leaves per palm (one leaf from each side). The measurements included:

a. Leaf length (m) and number of pinnae.

b. Average length of pinnae and spine $(\mathrm{cm})$ were determined as follows: 8 leaflets (4 from each side) at either the top, middle and the base of rachis were randomly collected and measured as well as pinnae width was measured.

4- Spathe male morphology: Some morphological characteristics of spathes of date palm males used in pollination were recorded at blooming. Five matured spathes were collected from each male palm used in pollination for the following spathe characteristics:
a. Spathe number.
b. Spathe length $(\mathrm{cm})$.
c. Spathe width $(\mathrm{cm})$.
d. Spathe weight $(\mathrm{kg})$.

e. Strand length $(\mathrm{cm})$.

f. Strand No./spathe.

g. Flower No./strand.

h. Weight of pollen grains ( $\mathrm{g}$ ).

5- Pollen grains characters: Five mature spathes of every male were collected as soon as they crashed and were dried at room temperature.

a. Pollen viability: It was tested with aceto-carmen-staining. One drop of $1 \%$ aceto-carmen was placed on a microscope slide, and then a small amount of pollen was dispersed and microscopically were examined. Colorless or unstained pollen grains were considered non-viable. Ten counts at different fields were examined and readings were recorded to determine the percentage of pollen viability according to El-Salhy et al. (1997).

b. Pollen germination: This test was carried out using a medium containing $7 \%$ sucrose +10 ppm boron $+1 \%$ agar in petri dishes. Fresh pollen grains were dusted on the previous medium and petri dishes were placed in an incubator at $27^{\circ} \mathrm{C}$ for 24 hours. So, pollen grains were microscopically examined for germination from each petri dish (Diab, 2012).

6- The number of fruit set per strands was counted using 10 strands per spathe after thirty days from pollination. The percentage of initial fruit set was calculated using the following equation:

Average No. of set fruit per

$$
\begin{aligned}
& \begin{array}{c}
\text { Initial fruit } \\
\text { set }(\%)
\end{array}=\frac{\text { strand }}{\text { Average No. of set fruit }+} \\
& \text { Average No. of flower scars }
\end{aligned}
$$

7- Evaluation of the tested male seedling date palm was calculated on the basis of 100 units which were divided among the five following characters, i.e. the spathes number, flowers number/palm, pollen grains weight, pollen grains viability and 
pollen grains germination (20 units for each). The following equation was used to determine these characters:

Characters $=\Sigma \mathrm{B} / \mathrm{A} \times 20$

Where: $A=$ The highest value recorded for studied character among all treatments.

$\mathrm{B}=$ Value recorded for the specific characters for considered treatments.

8- Bunches of both Seewy and Barhee date palm cultivars were picked at optimum commercial harvesting time under Fayoum Governorate conditions (i.e. the second week of both August and September).

- The average bunch weight $(\mathrm{kg})$ was determined for each pollinizer as well as the yield of each palm was recorded in terms of weight in kilograms.

- At harvesting date, fifteen fruits from each bunch were picked at ripe stage (Khlal) and divided into three replicates each containing five fruits.

- The obtained sample were studied in the laboratory to determine the fruit physical and chemical characteristics: The fruit flesh and seed weight were obtained in ( $\mathrm{g}$ ) by weighing each replicate (five fruits) and the average was calculated. Also fruit dimensions (axial and equatorial diameter) for the individual fruits were measured by a vernier caliper.

- Concerning moisture and dry matter contents, fruit samples were cleaned and date flesh was cut into pieces and dried at $60-65^{\circ} \mathrm{C}$ for 48 hours (Dawson and Aten, 1963 and Mawlood, 1980).

- The total soluble solids (TSS) content was determined in fruit juice using a hand refractometer (A.O.A.C., 1995).

- Total and reducing sugars percentages were determined in juice according to
A.O.A.C. (1995). The non-reducing sugars were calculated from the difference between total and reducing sugars. In addition, titratable acidity was determined in well mixed fruit juice $(5 \mathrm{ml})$ by titration against sodium hydroxide $(0.1 \quad \mathrm{~N}) \quad$ using phenolphthalein as an indicator, as described by A.O.A.C. (1995).

- Acidity percentage was calculated as g citric acid/100g. f.w.

- Also, tannins content was determined by using the Indigo Carmen indicator described by Balbaa (1981).

Inter simple sequence repeat DNA-PCR (ISSR-PCR) procedure:

1- ISSR-PCR reactions were conducted using five primers. Amplification was conducted in $25 \mathrm{ml}$ reaction volume containing the following reagents: $2.5 \mathrm{ml}$ of dNTPS (2.5 mmol), $2.5 \mathrm{ml} \mathrm{MgCl} 2$ (2.5 $\mathrm{mmol}$ ) and $2.5 \mathrm{ml}$ of $10 \mathrm{x}$ buffer, $3.0 \mathrm{ml}$ of primer $(10 \mathrm{pmol}), 3.0 \mathrm{ml}$ of template DNA $(25 \mathrm{mg} / \mathrm{ml}), \quad 1 \mathrm{ml}$ of Taq polymerase $(1 \mu / \mathrm{ml})$ and $12.5 \mathrm{ml}$ of sterile $\mathrm{H}_{2} \mathrm{O}$.

2- The PCR products were separated on a $105 \%$ agarose gel and fragments sizes were estimated with the $100 \mathrm{bp}$ ladder DNA marker (Fermentas) with molecular size of $1000,900,800,700,600,500$, 400, 300, 200 and $100 \mathrm{bp}$.

The DNA amplifications were performed in an automated thermal cycle (model Techno 512) programmed for one cycle at $94^{\circ} \mathrm{C}$ for $4 \mathrm{~min}$ followed by 45 cycles of $1 \mathrm{~min}$ at $94^{\circ} \mathrm{C}, 1 \mathrm{~min}$ at $57^{\circ} \mathrm{C}$, and $2 \mathrm{~min}$ at $72^{\circ} \mathrm{C}$. The reaction was finally stored at $72^{\circ} \mathrm{C}$ for $10 \mathrm{~min}$.

PCR reactions were conducted using 5 arbitrary 10-mer primers. Their names and sequences are shown in Table (1). 
Table 1. List of the primer names and their nucleotide sequences used in the study for ISSR procedure.

\begin{tabular}{ccccccc}
\hline No. & Name & Sequence & No. & Name & Sequence \\
\hline $\mathbf{1}$ & HB08 & 5` GAG AGA GAG AGA GG 3` & $\mathbf{4}$ & HB13 & 5` & GAG GAGGAG GC \\
$\mathbf{2}$ & HB09 & 5` GTG TGT GTG TGT GC 3` & $\mathbf{5}$ & HB15 & 5` GTG GTGGTG GC 3` \\
$\mathbf{3}$ & HB11 & 5` GTG TGT GTG TGT TGT CC3` & & & & \\
\hline
\end{tabular}

\section{Statistical analysis:}

All obtained data was tabulated and statistically analysed according to Snedecor and Cochran (1980) using the new L.S.D test for distinguishing the significance differences between various treatment means. The DNA bands generated by each primer were counted and their molecular sizes were compared with those of the DNA markers. The bands scored from DNA profiles generated by each primer were pooled together. Then the presence or absence of each DNA band was treated as a binary character in a data matrix (coded 1 and 0 , respectively) to calculate genetic similarity coefficients (Dice, 1945) and implemented in the computer program SPSS- 10.

\section{RESULTS AND DISCUSSION}

\section{1- Vegetative characteristics:}

Data in Table (2) described the vegetative characteristics of the twenty investigated male palms. Data cleared that great variability in vegetative traits of various males. Palm heights were differed, the values were ranged from 4.91 to $10.72 \mathrm{~m}$ where male No. 12 was the tallest $(10.72 \mathrm{~m})$ and the shortest male was No. $20(4.91 \mathrm{~m})$. Meanwhile the corresponding girth of palm were ranged from (1.46 to $2.16 \mathrm{~m})$ where male No. 12 was the biggest $(2.16 \mathrm{~m})$ as compared to the other male palms. Also, data in Table (2) indicated that the annual leaves number per palm was variable, where the annual leaves number was ranged from 13 to 18 leaves/palm. Regarding the leaf characteristics, data in Table (2) showed that the leaf length ranged from 3.66 to $4.11 \mathrm{~m}$ in the different male palms. The spines number per leaf was ranged from 20 to 21 spines/leaf. Also, the pinnae number per leaf were ranged from 193 to 209 pinnae/leaf, while length and width of pinnae were ranged from $(42.3$ to $52.8 \mathrm{~cm})$ and $(2.46$ to $3.34 \mathrm{~cm}$ ), respectively. These findings might be due to increase either the leaf number or leaf area which reflected on a pronounced increase in leaf surface and enhanced the vegetative growth and both viability and germination of pollen grains. These results agreed generally with those found by Diab (2012).

\section{2- Morphological spathe characteristics of different male palms:}

Data in Table (3) indicated that great variability in the morphological traits of the spathes of various male palms. The spathe number ranged from 15 to 34 spathes/palm in the different males. The recorded spathe length and width ranged from 79 to 150 and 10 to $19 \mathrm{~cm}$, respectively corresponding to the average of the two studied seasons. The corresponding spathe weight ranged from 1.5 to $3.65 \mathrm{~kg}$ whereas for strand length ranged from 195 to $497 \mathrm{~cm}$. Also, strands number per spathe ranged from 72 to 140 strand per spathe. Data in Table (3) indicated that the average number of flowers per strand varied from 50 to 130 flowers/strand. The corresponding weight of pollen grains varied from 280.5 to $1630 \mathrm{~g} / \mathrm{spathe}$.

Also, data in Table (3) indicated that beginning of the spathe crashing started from $5^{\text {th }}$ Feb. to $22^{\text {nd }} F e b$. Data also revealed that end of spathe crashing was from $10^{\text {th }}$ March to $24^{\text {th }}$ March. These results are in agreement with El-Sabrouit (1979); Nasr et al. (1986); Marzouk et al. (2002) and Diab (2012). 
Table 2. Vegetative characteristics of twenty males of date palm used in pollination. Data represented the average of the two studied seasons (2011 and 2012).

\begin{tabular}{ccccccccc}
\hline Characters & $\begin{array}{c}\text { Height } \\
\text { (m) }\end{array}$ & $\begin{array}{c}\text { Girth } \\
(\mathbf{m})\end{array}$ & $\begin{array}{c}\text { No. of } \\
\text { annual } \\
\text { leaves/palm }\end{array}$ & $\begin{array}{c}\text { Leaf } \\
\text { length } \\
\text { (m) }\end{array}$ & $\begin{array}{c}\text { Spines } \\
\text { No./leaf No. /leaf }\end{array}$ & $\begin{array}{c}\text { Pinnae } \\
\text { length } \\
\text { (cm) }\end{array}$ & $\begin{array}{c}\text { Pinnae } \\
\text { width } \\
\text { (cm) }\end{array}$ \\
\hline Male 1 & 5.69 & 1.80 & 15 & 3.84 & 22 & 197 & 42.3 & 2.63 \\
Male 2 & 6.45 & 1.78 & 14 & 3.74 & 21 & 193 & 44.2 & 2.69 \\
Male 3 & 6.56 & 1.60 & 13 & 3.95 & 22 & 195 & 45.6 & 2.66 \\
Male 4 & 7.48 & 1.90 & 14 & 3.91 & 21 & 199 & 51.3 & 2.73 \\
Male 5 & 10.65 & 2.00 & 18 & 3.82 & 25 & 203 & 50.6 & 3.30 \\
Male 6 & 6.93 & 1.83 & 16 & 3.99 & 20 & 201 & 42.1 & 2.81 \\
Male 7 & 8.80 & 1.94 & 17 & 4.00 & 24 & 205 & 48.2 & 3.21 \\
Male 8 & 6.33 & 1.52 & 16 & 3.73 & 23 & 195 & 43.1 & 2.84 \\
Male 9 & 5.74 & 1.46 & 15 & 3.62 & 22 & 197 & 44.2 & 2.94 \\
Male 10 & 8.30 & 1.64 & 15 & 3.76 & 22 & 191 & 45.7 & 2.61 \\
Male 11 & 7.00 & 1.61 & 14 & 3.69 & 21 & 193 & 46.4 & 3.10 \\
Male 12 & 10.72 & 2.16 & 18 & 3.96 & 24 & 207 & 52.6 & 3.34 \\
Male 13 & 9.80 & 1.87 & 17 & 3.89 & 26 & 209 & 52.8 & 3.16 \\
Male 14 & 9.93 & 1.92 & 17 & 4.11 & 27 & 199 & 51.9 & 3.28 \\
Male 15 & 6.20 & 1.58 & 16 & 3.77 & 24 & 201 & 47.5 & 2.95 \\
Male 16 & 6.40 & 1.63 & 15 & 3.80 & 23 & 193 & 49.2 & 2.46 \\
Male 17 & 7.35 & 1.75 & 16 & 3.83 & 25 & 197 & 45.3 & 2.56 \\
Male 18 & 7.15 & 1.72 & 14 & 3.79 & 22 & 199 & 47.8 & 2.86 \\
Male 19 & 6.83 & 1.68 & 13 & 3.85 & 21 & 201 & 43.5 & 2.93 \\
Male 20 & 4.91 & 1.59 & 14 & 3.66 & 23 & 193 & 42.8 & 2.58 \\
\hline
\end{tabular}

It was evident from foregoing results that the seedling males differ greatly in the morphological characteristics of the spathes and strands. These results are in agreement with Nasr et al. (1986); Marzouk et al. (2002) and Diab (2012). They stated that no two seedling palms are similar and of course they had different growth characteristics of spathes in seedling males.

\section{3- Pollen grains characteristics:}

The viability percentage of twenty date pollinators are presented in Table (3). It was cleared that viability percentage was averaged from 89.9 to $100 \%$. The corresponding germination percentage of the twenty pollinators were attained from 85 to $100 \%$. It could be concluded that the germination percentage took a similar trend to that of the viability percentage. Generally, it was noticed that there was a positive relationship between pollen viability and germination percentage. These results are in line with those established by Hamdy (1982), El-Salhy et al. (1997) and Diab (2012). They found that the pollen grains of the date palm males showed wide variation in both viability and germination percentage.

\section{4- General Evaluation:}

The general evaluation of males date palm seedlings are summarized in Table (4). The male No. 5 and No. 14 rank at the first in the general evaluation as it attained the maximum accumulative units (98.9 and 98.8 units, respectively) as compared to the other males. Male No. 7 gave the second, it attained 83.6 units. The third rank was gained by the males No. 12 and No. 13, as they attained 81.9 and 81.8 units, respectively).In general, there were five males, which were found to be good pollinators (M5, M14, M7, M12 and M13). 


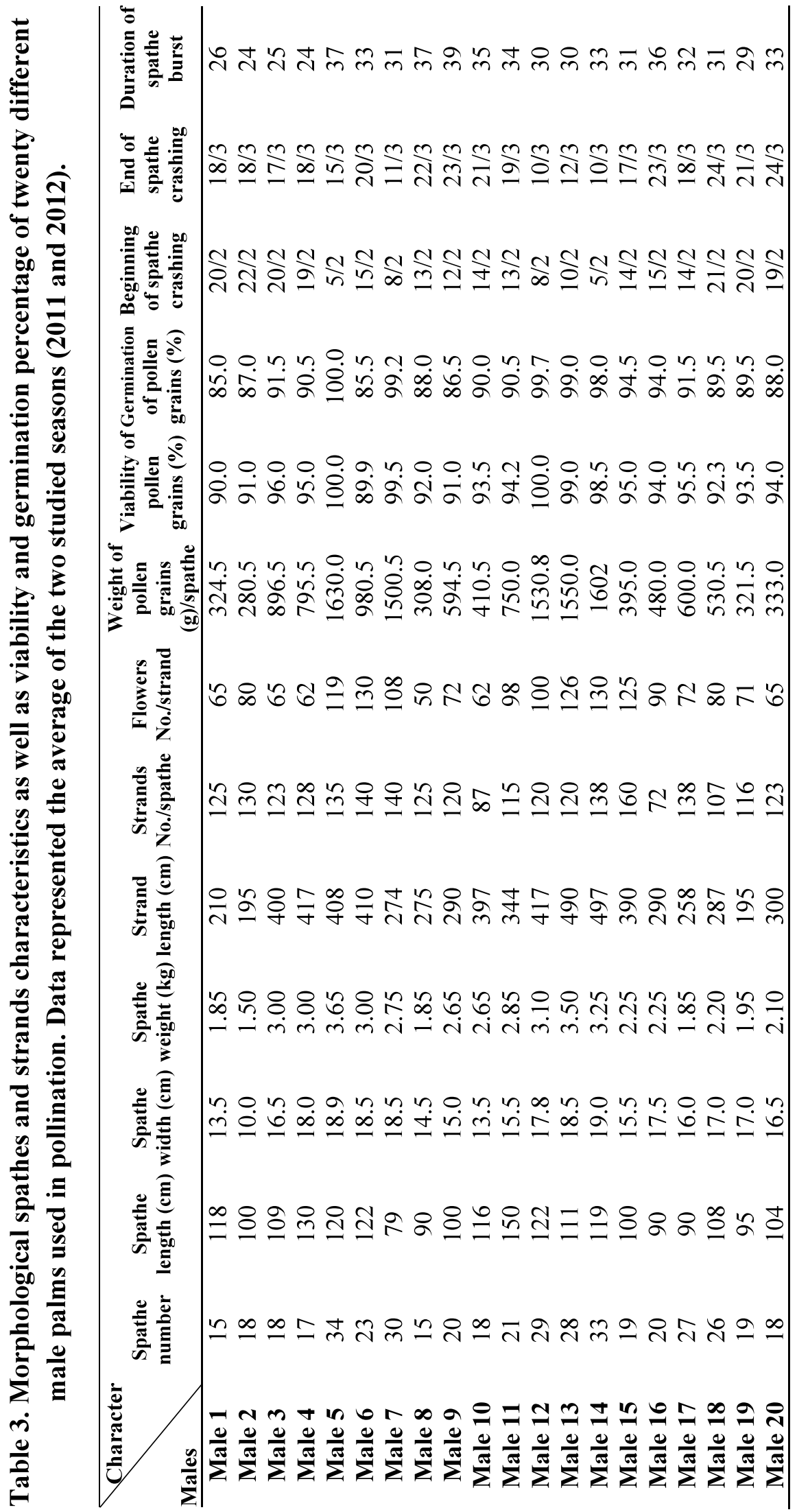


Table 4. General evaluation of selected male date palm seedlings.

\begin{tabular}{|ccccccc}
\hline Character & $\begin{array}{c}\text { No. of } \\
\text { spathe/palm }\end{array}$ & $\begin{array}{c}\text { No. of } \\
\text { flowers/palm }\end{array}$ & $\begin{array}{c}\text { Start of } \\
\text { spathe burst }\end{array}$ & $\begin{array}{c}\text { Weight of } \\
\text { pollen grains } \\
\text { (g)/palm }\end{array}$ & $\begin{array}{c}\text { Viability of } \\
\text { pollens grains } \\
\text { \%o }\end{array}$ & $\begin{array}{c}\text { General } \\
\text { evaluation of } \\
\text { males }\end{array}$ \\
\hline specified & & & & & & \\
Malex units & & & & & & \\
Seedling & $\mathbf{2 0}$ & $\mathbf{2 0}$ & $\mathbf{2 0}$ & $\mathbf{2 0}$ & $\mathbf{2 0}$ & $\mathbf{1 0 0}$ units \\
\hline M1 & & & & & & \\
M2 & 8.8 & 4.6 & 5.0 & 3.9 & 18.0 & 40.3 \\
M3 & 10.6 & 6.7 & 4.6 & 3.4 & 18.2 & 43.5 \\
M4 & 10.6 & 5.5 & 5.0 & 11.0 & 19.2 & 51.3 \\
M5 & 10.0 & 4.9 & 5.3 & 9.8 & 19.0 & 49.0 \\
M6 & 20.0 & 18.9 & 20.0 & 20.0 & 20.0 & 98.9 \\
M7 & 13.5 & 10.7 & 6.7 & 12.0 & 17.98 & 60.88 \\
M8 & 17.7 & 15.1 & 12.5 & 18.4 & 19.9 & 83.6 \\
M9 & 8.8 & 3.5 & 7.7 & 3.8 & 18.4 & 42.2 \\
M10 & 11.8 & 6.7 & 8.3 & 7.3 & 18.2 & 52.3 \\
M11 & 10.6 & 5.2 & 7.1 & 5.0 & 18.7 & 46.6 \\
M12 & 12.4 & 9.6 & 7.7 & 9.2 & 18.8 & 57.7 \\
M13 & 17.1 & 13.5 & 12.5 & 18.8 & 20.0 & 81.9 \\
M14 & 16.5 & 16.5 & 10.0 & 19.0 & 19.8 & 81.8 \\
M15 & 19.4 & 20.0 & 20.0 & 19.7 & 19.7 & 98.8 \\
M16 & 11.2 & 11.1 & 7.1 & 4.9 & 19.0 & 53.3 \\
M17 & 11.8 & 8.4 & 6.7 & 5.9 & 18.8 & 51.6 \\
M18 & 15.9 & 9.1 & 7.1 & 7.4 & 19.1 & 58.6 \\
M19 & 15.3 & 9.7 & 4.8 & 6.5 & 18.5 & 54.8 \\
M20 & 11.2 & 6.3 & 5.0 & 3.9 & 18.7 & 45.1 \\
& 10.6 & 5.5 & 5.3 & 4.1 & 18.8 & 44.3 \\
\hline
\end{tabular}

These units are the sum of the units presenting the inclusive evaluation of spathes number/palm, flowers number/palm, start and duration of spathes burst, pollen grains weight/spathe, pollen grains viability. These results are in agreement with those found by Mohamed (2004) and Diab (2012).

\section{5- Fruit set percentage and fruit physical characteristics:}

Data presented in Table (5) showed the average fruit set, fruit weight, flesh weight, seed weight, fruit length and fruit diameter of both Seewy and Barhee cultivars.

\section{a. Fruit set (\%):}

The obtained data indicated that fruit set percentage was significantly affected by different male pollinators for both Seewy and Barhee cultivars in both seasons. Pollinizers No. 5, 12 and 14 gave the highest fruit set percentage as Seewy recorded (100, 100 and $100 \%$ for No. 5, 12 and 14, respectively). Also, Barhee recorded 97.67, 98.17 and $99.17 \%$ from pollinizers No. 5, 12 and 14 respectively.

\section{b. Fruit physical characteristics:}

\section{- Fruit weight:}

The same trend was noticed in Seewy fruit weight $(18.5,19.17$ and $19.54 \mathrm{~g}$ for pollinizers No. 5, 12 and 14 respectively). Meanwhile, Barhee gave the highest fruit weight 14.26, 14.05 and $14.74 \mathrm{~g}$ from pollinizer trees No. 12, 13 and 14 respectively.

\section{- Flesh weight:}

It was noticed from the obtained data that during the two seasons in both Seewy and Barhee cultivars the flesh weight exhibits similar trends for the fruit weight.

\section{- Seed weight:}

The data of seed weight indicated that there were significant differences in both 


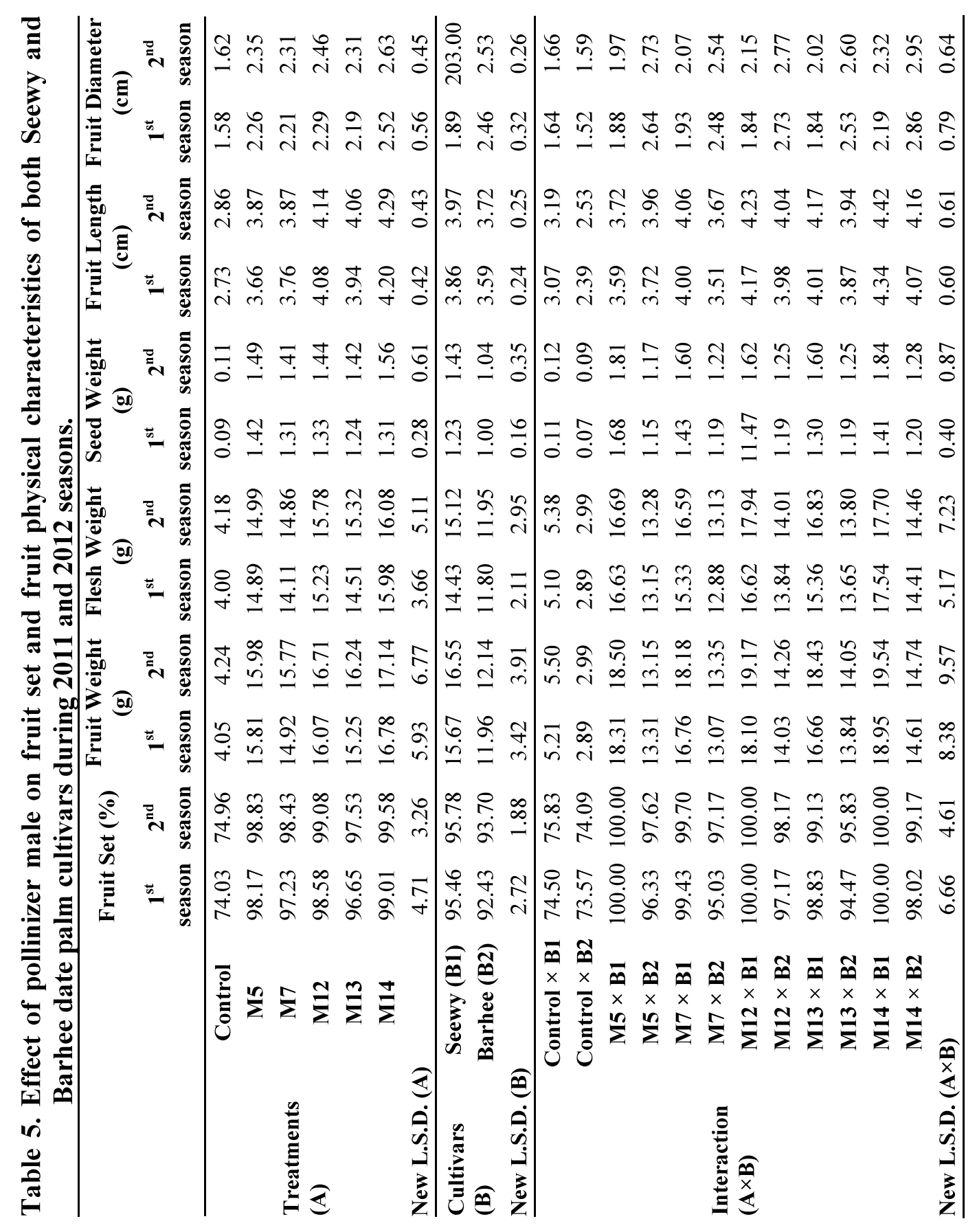


seasons. The control in Barhee cultivar gave the lowest seed weight, but Barhee seed weight for pollinizer No. 5 gave the lowest seed weight (1.15 and $1.17 \mathrm{~g}$ in the first and second seasons, respectively).

These results agreed generally with those found by Nasr et al. (1982); Osman and Soliman (2002) and Diab (2012).

\section{- Fruit length:}

Regarding the effect of different male pollinators on fruit length, data in Table (5) and Fig. (1) indicated that pollinizers No. 7, 12,13 and 14 gave the highest values of fruit length in both seasons for Seewy cultivar.

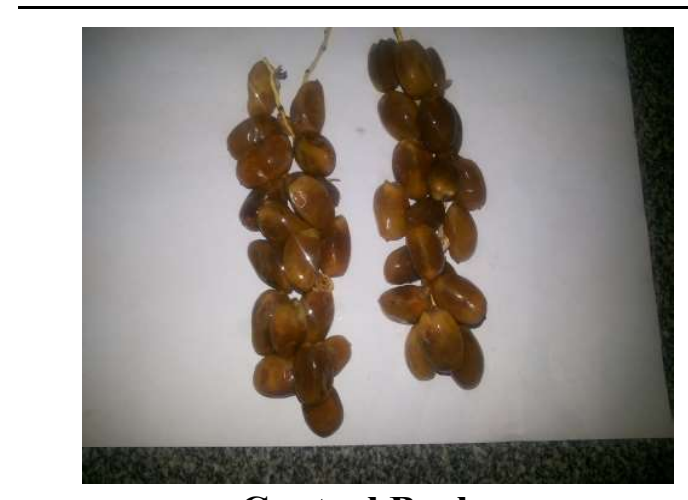

Control Barhee

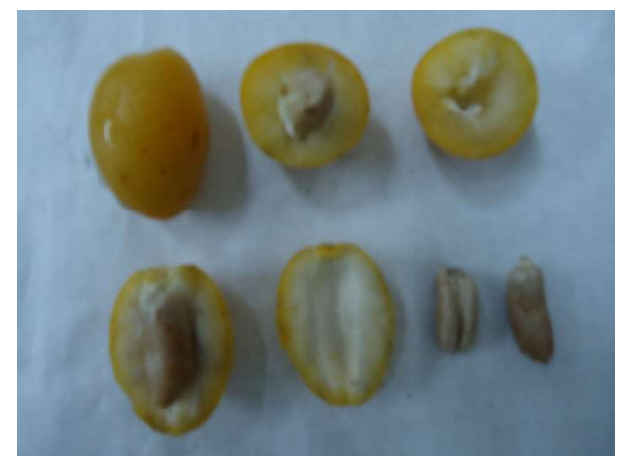

Barhee cultivar



Control Seewy

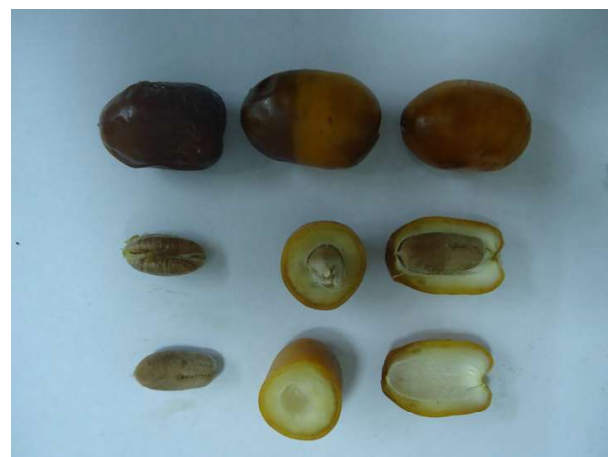

Seewy cultivar

Fig. 1. Effect of pollinizers on fruits of both Seewy and Barhee cultivars as well as control (un-pollinated) fruits.

Osman and Soliman (2002) reported that fruit length was affected by type of pollen; these data are in partial agreement with those reported by Soliman (1999) on Samany and Sakkoty cultivars.

\section{- Fruit diameter:}

Also data in Table (5) showed also that significant differences in fruit diameter in both seasons. Pollinizer No. 14 gave the highest fruit diameter in both seasons for both Seewy and Barhee cultivars. These results agree with those found by Soliman (1999), Osman and Soliman (2002) and Diab (2012).

\section{6- Fruit chemical characteristics:}

Data presented in Table (6) showed the average moisture percentage, dry matter, total soluble solids (TSS), reducing, nonreducing sugars and total sugars, total acidity and tannins percentage.

\section{a. Moisture (\%):}

Regarding the moisture percentage, the data obtained indicated that there were significant differences among all treatments for Seewy and Barhee cultivars in both two seasons. Pollinizer No. 7 gave the highest moisture percentage for the Barhee cultivar in both two seasons. 


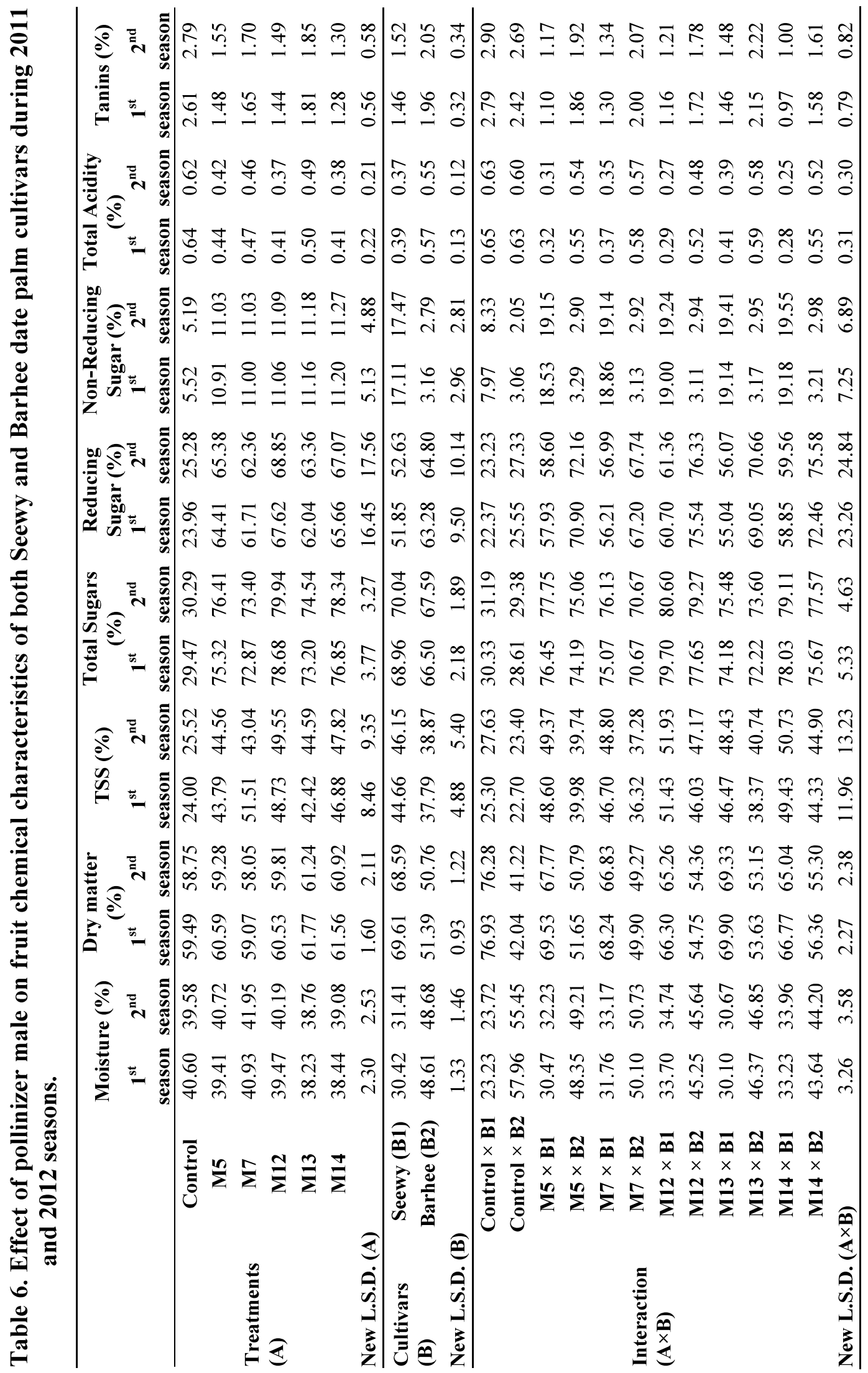


These data are in partial agreement with those reported by Soliman (1999) and Osman and Soliman (2002).

\section{b. Dry matter (\%):}

Data showed that significant differences in dry matter content percentage in both seasons. Pollinizer No. 13 gave the highest dry matter percentage (69.9 and $69.3 \%$ in both two seasons, respectively) for Seewy cultivar.

\section{c. Total soluble solids (TSS \%):}

Total soluble solids percentage was significantly increased by different male pollinators in both seasons. Pollinizer No. 12 gave the highest values for Seewy cultivar in both seasons (51.43 and 51.93\%, respectively). These results are in agreement with Osman and Soliman (2002) and Diab (2012) who found that total soluble solids percentage significantly increased by different male pollinators.

\section{d. Reducing sugars (\%):}

The obtained data in Table (6) indicated that the reducing sugars percentage was significantly affected by different male pollinators in both seasons. Pollinizer No. 12 gave the highest values of reducing sugars \% in Barhee cultivar (74.54 and 76.33, respectively) in both seasons. These data are in partial agreement with Soliman (1999) on Samany and Sakkoty cultivars and Osman and Soliman (2002).

\section{e. Non-reducing sugars (\%):}

The non-reducing sugars percentage increased significantly by different male pollinators in the two seasons. Pollinizer No. 14 gave the highest non-reducing sugars (19.18 and $19.55 \%$, for Seewy cultivar). These results are partially in agreement with Osman and Soliman (2002) and Diab (2012).

\section{f. Total sugars (\%):}

Concerning the effect of different male pollinators on total sugars percentage, data in Table (6) showed a significant increase by different male pollinators. Pollinizer No. 12 gave the highest values of total sugars percentage in Seewy cultivar of both two seasons (79.70 and $80.60 \%)$. These results are partially in agreement with Soliman (1999) and Osman and Soliman (2002).

\section{g. Total acidity (\%):}

The obtained data indicated that pollinizer No. 13 produced the highest values in both seasons $(0.59$ and $0.58 \%)$ for Barhee cultivar. The present data are in partial agreement with those reported by Osman and Soliman (2002), Diab (2012) and Abo-Rekab et al. (2013).

\section{h. Tannins content (\%):}

Concerning the effect of different male pollinators on tannins $\%$, data indicated that pollinizer No. 13 gave the highest values of tannins percentage in two seasons for Barhee cultivar (2.15 and 2.22\%, respectively). These results are in agreement with those reported by Abo-Rekab et al. (2013).

Data in Table (7) showed the harvesting date, bunch weight and yield/palm. The obtained data indicated that pollinizer No. 12 induced early harvesting for Barhee cultivar compared with the control and Seewy cultivar. Pollinizer No. 7 gave the highest bunch weight and yield/palm in both two seasons for both two cultivars (Seewy and Barhee). These results are in agreement with those established by Marzouk et al. (2002) and Abo-Rekab et al. (2013).

\section{7- Identification of ISSR-PCR markers:}

ISSR was a class of molecular markers based on inter-tandem repeats of short DNA sequences. These inter repeats were highly polymorphic, even among closely related genotypes due to the lack of functional constraints in these non-functioning regions. Similarly a high level of polymorphism was generated utilizing the two ISSR-PCR primers. A total number of 41 ISSR bands were obtained; of these 41 bands, 23 bands were polymorphic $(56.1 \%)$ and 18 were monomorphic (43.9\%). The highest number of applicants was generated. Polymorphism levels differed from one primer to the other. 


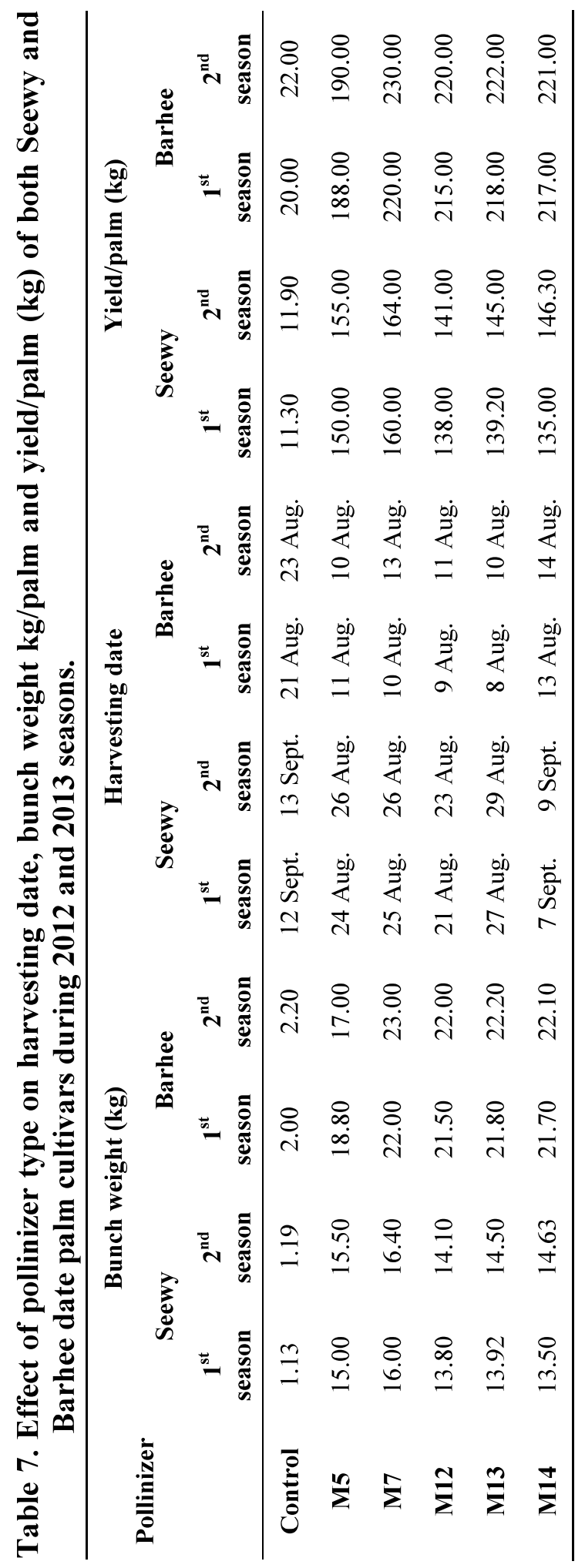


Both primer HB-08 and HB-09 generated $33.33 \%$ and HB-11 generated $60.0 \%$ which exhibited high polymorphisms. On the other hand, primer HB-15 exhibited low polymorphism (12.5\%). The numbers of total amplified fragments, polymorphic, monomorphic and unique bands for each primer for each of five male pollinizers using the five primers are shown in Table (8). There were some specific fragments discriminated each five male pollinizers from the others as follows: primer HB-08 did not show any specific fragments. Primer HB-09 showed two specific fragments as positive marker. Primer HB-11 showed two specific fragments as one positive marker and the other was negative marker. Primer HB-13 showed one specific fragment as positive marker. Primer HB-15 showed three specific fragments, all of them as positive markers.

Table 8. Total number of bands, polymorphic bands, monomorphic bands and unique band as well as polymorphic \% of the 5 selected male plalms.

\begin{tabular}{cccccc}
\hline Primer name & $\begin{array}{c}\text { Total } \\
\text { band }\end{array}$ & $\begin{array}{c}\text { Polymorphic } \\
\text { band }\end{array}$ & $\begin{array}{c}\text { Monomorphic } \\
\text { band }\end{array}$ & Unique band & Polymorphic \% \\
\hline HB-08 & 9 & 3 & 6 & -- & 33.33 \\
HB-09 & 6 & 2 & 2 & 2 & 33.33 \\
HB-11 & 10 & 6 & 2 & 2 & 60.00 \\
HB-13 & 8 & 3 & 4 & 1 & 37.50 \\
HB-15 & 8 & 1 & 4 & 3 & 12.50 \\
Total & $\mathbf{4 1}$ & $\mathbf{1 5}$ & $\mathbf{1 8}$ & $\mathbf{8}$ & \\
\hline
\end{tabular}

\section{8- Genetic similarity and cluster analysis based on ISSR markers:}

The ISSR data were used to estimate the genetic similarity among the five male pollinizers by using UPGMA. Computer analysis are presented in Table (9) and Fig. (2). The highest similarity index (1.0) was recorded between male pollinizer No. 12 and No. 14, while no similarity was detected (0.0) between male pollinizer No. 12 and No. 13. A dendrogram for the genetic relationships among the five male pollinizers was drawn in Fig. (3). The results of ISSR are in harmony with Younis et al. (2011) and Abo-Rekab (2013).

Table 9. Genetic similarity matrices among the five male pollinizers accessions as computed according to Dice coefficient from ISSR.

\begin{tabular}{lcccc}
\hline & M5 & M7 & M12 & M13 \\
M7 & 0.47 & & & \\
M12 & 0.96 & 0.64 & & \\
M13 & 0.80 & 0.83 & 0.64 & \\
M14 & 0.67 & 0.86 & 1.0 & 0.0 \\
\hline
\end{tabular}

\section{REFERENCES}

Abo-Rekab, Zeinab A.M. (2013). The genetic diversity analysis of some Egyptian oasis seedling date palm fruits and its physical characteristics and chemical composition. J. Biol. Chem. Environ. Sci., 8(3):433-450.

Abo-Rekab, Zeinab, A.M.; Tahany Y. Saber and Mohamed, A.M. (2013). Selected date palm pollen grains constitute and their effect on improving productivity and fruit quality of Seewy and Sultany date palm cultivars. J. Biol. Chem. Environ. Sci., 8(3):479-497.

A.O.A.C. (1995). Official Methods of Analysis of the Association of Analytical Chemists, $14^{\text {th. }}$ Ed., Benjamin Franklin, Washington D.C. (USA).

Balbaa, S.P. (1981). Chemistry of crude drugs (Laboratory Manual), Cairo Univ. Chapter 6, pp. 127-137.

Becelaere, V.G.; Lubbers, E.L.; Pareson, A.H. and Chee, P.W. (2005). Pedigree vs. DNA marker-based genetic similarity estimates in cotton. Crop Sci., 45: 22812287. 


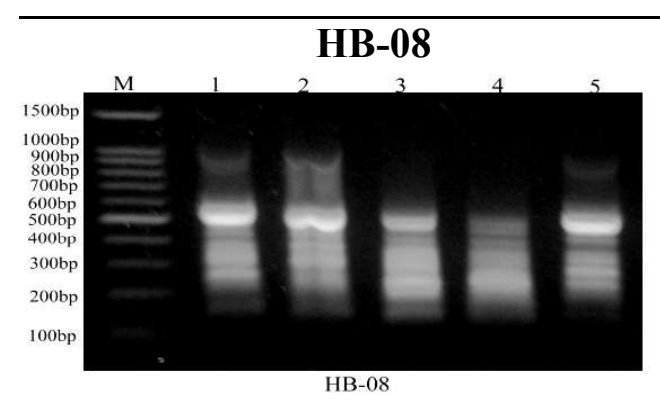

HB-11
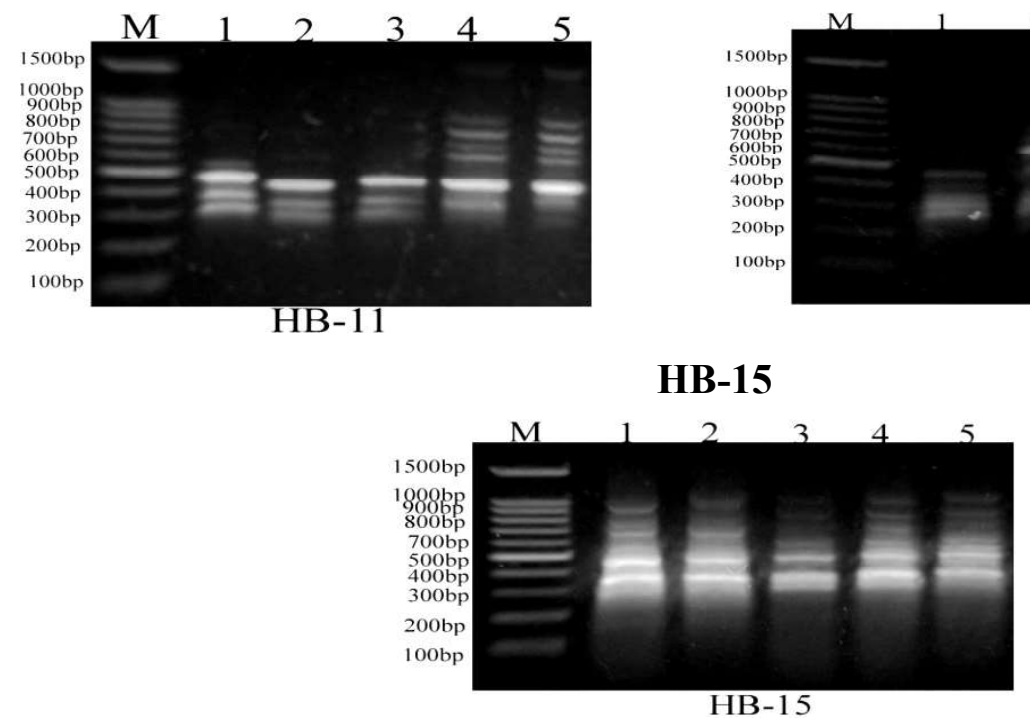

Fig. 2. ISSR products generated with primers HB-08, HB-09, HB-11, HB-13 and HB-15 in five pollinizers.

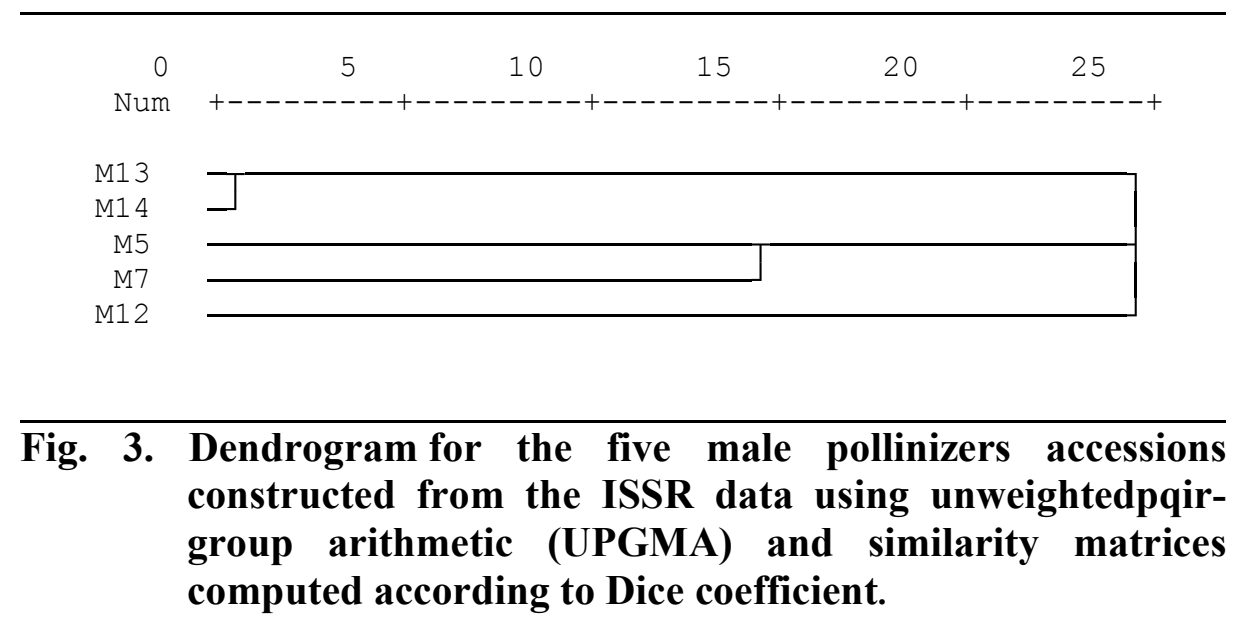

Dawson V.H.W. and Aten, A. (1963). Dates handling processing and packing F.A.O. Agricultural development paper No. 72. Food and Agriculture Organization of the United Nations, Rome.

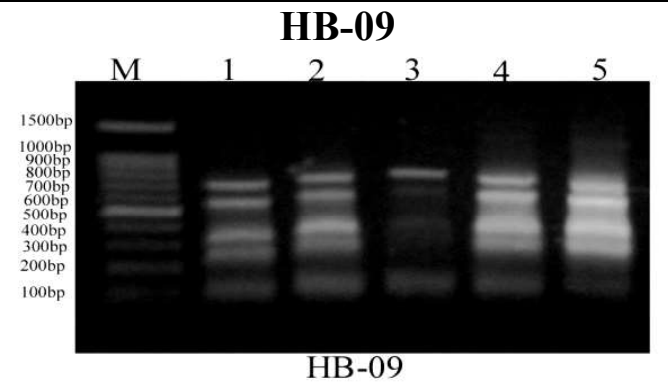

HB-13

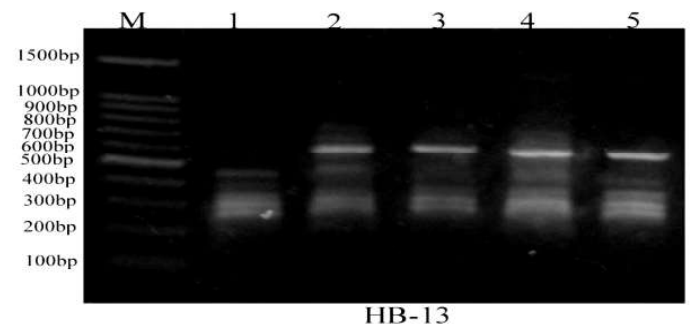

$\mathrm{HB}-13$ 
Dice, L.R. (1945). Measures of the amount of ecologic association between species. Ecology, 26:297-302.

El-Sabrout, M.B. (1979). Some Physiological Studies on The Effect of Pollen Type on Fruit Setting and Fruit Quality in Some Date Palm Verities. M.Sc. Thesis, Fac. Agric. Alex. Univ., Egypt.

El-Salhy, A.; Abdalla, A.Y. and Mostafa, R.A. (1997). Evaluation of some date palm male seedlings in pollination of Zaghloul and Samany date palms under Assuit conditions. Assuit J. Agric. Sci., 28(2):79-89.

Hamdy, Z.M. (1982). Studies on date pollen characters of some date varieties and their effect on fruit anatomy of Amhat dates. Agric. Res. Review, 60(3):1-20.

Kotb, A. (1993). Studies on pollination, fertilization and the effect of some hormonal treatments on three date cultivars. Third Symp. on Date Palm in Saudi Arabia, Faisal Univ., Al-Hassa. Saudi Arabia. January, 1993.

Marzouk, H.M.M.; El-Salhy, A.M. and Hassan, R.A. (2002). Effect of pollination on fruit set, yield and fruits quality of Zaghloul and Samany date palm cultivars. A- Evaluation of five seedling date palm males and their effect on yield and fruit quality. Proc. Minia $1^{\text {st }}$ Conf. for Agric. and Environ. Sci., Minia, Egypt, pp. 983-998.

Mawlood, E.A. (1980). Physiological Studies on Fruits Development of Samani and Zaghloul Date Palm Cultivars. Ph.D. Thesis, Hort. Dept., Fac. Agric. Cairo Univ., Egypt, pp. 110.

Mohamed, M.A. (2004). Evaluation and Selection of Some Seedling Date Palm
Males and Their Effect on Fruiting Quality of Seewy Date Palms. M.Sc. Thesis, Fac. Agric., Fayoum Univ., Egypt.

Nasr, M.A.; Haq, M.I. and Sabrout, M.B.I. (1982). Effect of pollination intervals on yield, fruit setting and other characters of Aseel date cultivar. Sarhad Journal of Agriculture., 13(4):351-355.

Nasr, T.A.; Shaheen, M.A. and Bacha, M.A. (1986). Evaluation of date palm males used in pollination in the central region, Saudi Arabia. The second symposium on the date palm in Saudi Arabia, March 36, vol. (1): 337-396.

Osman, S.M. and Soliman, S.S. (2002). Effect of different pollen grains and pollination time on fruit quality of Zaghloul date cultivar under North Sinai conditions. Assuit Journal of Agricultural Science, 33(5):47-58.

Younis Rania A.A.; Omayma M. Ismail and Soliman, S.S. (2011). Identification of sex-specific DNA markers for date palm (Phoenix dactylifera L.) using RAPD and ISSR techniques. Arab Palm Conference 2011. The first scientific conference for the development of the date palm and dates sector in the Arab world. 4-7 December 2011. Head Quarters-King Abdullah Road-Riyadh, KSA.

Snedecor, G.W. and Cochran, W.G. (1980). Statistical methods $7^{\text {th }}$ Ed. Iowa State Univ. Press. Ames. Iowa, USA, pp. 507.

Soliman, S.S. (1999). Effect of Pollen Source on Fruiting and Fruit Characteristics of Two Date Palm Cultivars Samany and Sakkoty. Ph.D. Thesis, Fac. Agric., Cairo Univ., Egypt. 
إنتخاب أفضل الآباء المذكرة لنخيل البلح لتحسين كلاً من المحصول وبعض صفات الجوردة للثئمار وتمييز

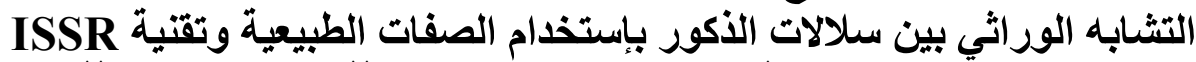



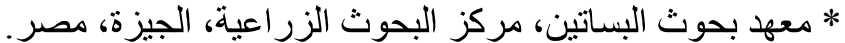

$$
\begin{aligned}
& \text { ** المعل المركزي لأبحاث وتطوير نخيل البلح، مركز البحوث الزير اعية، الجيزة، مصر. }
\end{aligned}
$$

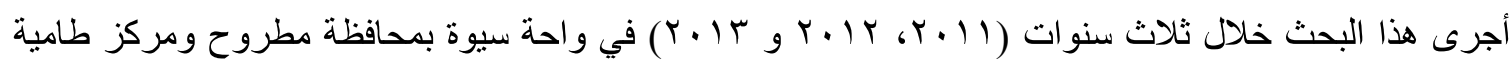



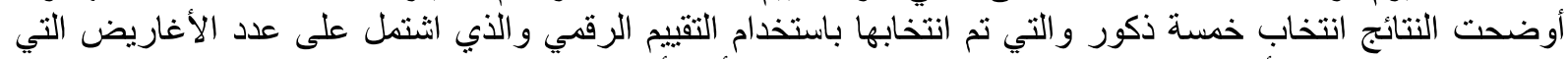

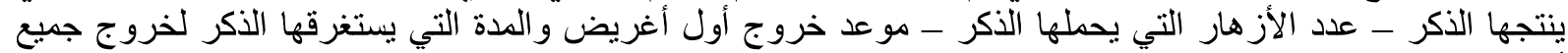

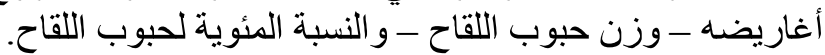

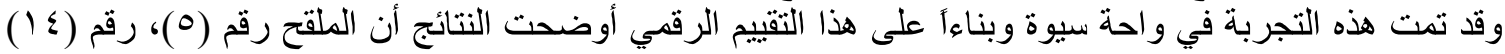

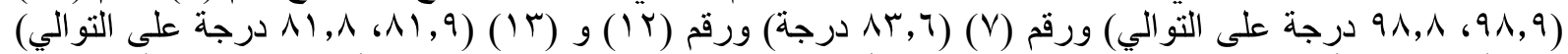

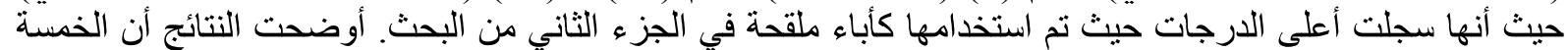

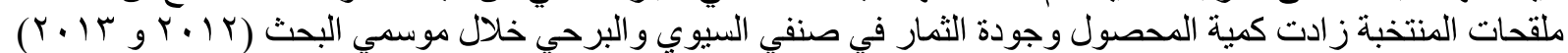

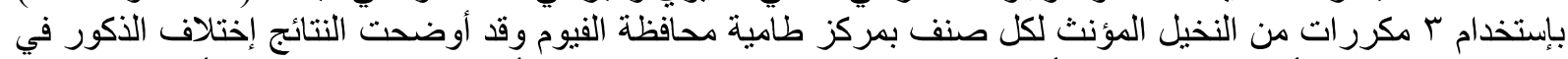

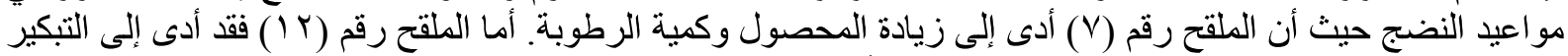

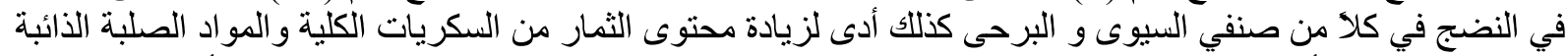



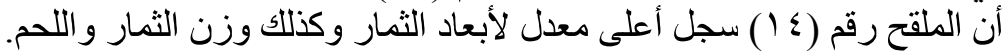

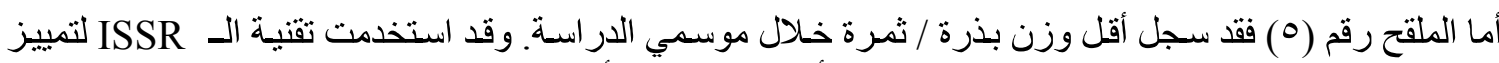

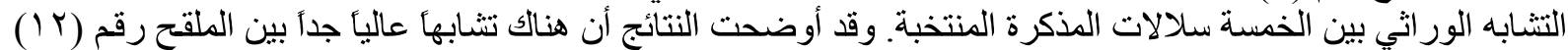

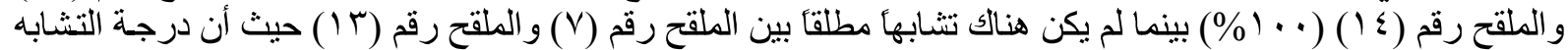

بينهما (صفر \%). 